\title{
KAJIAN PENDAPATAN PENGELOLAAN WADUK BATU BESI PLTA KAREBBE
}

\author{
Andi Kartini Sari ${ }^{1}$ \\ ${ }^{1}$ Dosen FT Universitas Andi Djemma Palopo \\ tin_sary@yahoo.com
}

\begin{abstract}
Abstrak
Waduk Batu Besi terletak di Kabupaten Luwu Timur Sulawesi Selatan, tampungan waduk dimanfaatkan untuk memenuhi kebutuhan operasional PT. INCO dalam pengolahan biji nikel yang bergerak di bidang pertambangan nikel. PLTA Karebbe merupakan pembangkit listrik tenaga air yang berlokasi di Karebbe di sungai Larona dengan kapasitas 90 MW. Kajian pola operasi waduk Batu Besi PLTA Karebbe dalam pengembangan dan pengelolaan 37 tahun kedepan, analisis pendapatan yang diperoleh dari pengelolaan waduk dihitung dari perkalian antara jumlah air yang dilepas waduk dengan harga satuan tarif dasar listrik dari masing masing kebutuhan, sehingga dapat diperhitungkan seberapa besar pemakaian listrik setiap bulanya dan seberapa besar pendapatan yang dihasilkan oleh PT. INCO selama 37 tahun kedepan (Tahun 1998-2035). Besarnya tenaga yang dikeluarkan sangat tergantung pada debit yang dialirkan dan tinggi tekanan efektif pada waduk tersebut. Seluruh biaya pengeluaran waduk diperhitungkan mulai sejak waduk beroperasi yang terdiri dari besarnya pendapatan yang diperoleh dan biaya operasi pemeliharaan waduk Batu besi. Pendapatan atas pemanfaatan air waduk dalam meningkatkatkan produktifitas nikel per tahun rata-rata diperoleh sebesar Rp.619.467.864.630,957 per Kwh dengan total pendapatan Rp.23.539.778,855 per Kwh, dengan total pemakaian daya listrik sebesar 69,631 GWh.
\end{abstract}

Kata kunci : Waduk Batu Besi, PLTA Karebbe Sorowako, Pendapatan Pengelolaan waduk.

\section{PENDAHULUAN}

Pembangunan waduk bertujuan untuk menampung kelebihan air pada musim hujan sebelum air masuk ke laut, dan akan dimanfaatkan pada musim kemarau atau dapat pula dimaksudkan untuk mengatur distribusi ketersediaan air guna memenuhi kebutuhan air pada tempat dan waktu tertentu. Salah satu aspek yang dominan dalam pengelolaan sumberdaya air waduk adalah operasi waduk. Beberapa faktor yang mempengaruhi operasional faktor kebutuhan air yang dinamis dan cenderung meningkat dari waktu kewaktu. Waduk Batu Besi yang beroperasi sejak Tahun 1988, sangat berperan dalam menentukan keberhasilan pemanfaatan sumberdaya air sebagai Pembangkit Lisrik Tenaga Air (PLTA), untuk memenuhi kebutuhan operasional PT. INCO yang bergerak di bidang Tambang Nickel di Kabupaten Luwu Timur Sulawesi Selatan. Upaya yang dilakukan untuk memenuhi kebutuhan energi listrik tenaga air adalah dengan mensinergiskan ketersediaan air dan kebutuhan air dalam bentuk pedoman operasi waduk yang diperoleh dari hasil analisis operasi waduk. Prinsip dasar dalam analisis ini adalah memprediksi perilaku dari suatu sistem sumberdaya air yang dituangkan dalam bentuk persamaan matematik, dan diformulasikan sesuai dengan tujuan sistem yang akan dicapai dengan parameterparameter yang mempengaruhi, maupun batasan yang ada. Sumberdaya air Waduk Batu Besi dimanfaatkan terutama, untuk kebutuhan Pembangkit Listrik Tenaga Air PT.International Nickel Indonesia. Kajian pola operasi waduk diperlukan untuk mengetahui berapa besar manfaat yang didapatkan terutama untuk mencukupi kebutuhan PLTA. Mengetahui potensi ketersediaan dan kebutuhan air pada waduk Batu Besi dalam pemanfaatan dan alokasi air secara optimal. Perencanan sumberdaya air waduk Batu Besi dapat diselesaikan dengan teknik optimasi dan simulasi sehingga kriteria optimal penggunaan air dapat tercapai, namun dalam 
penelitian ini dengan menggunakan simulasi sudah mampu menyelesaikan persoalan yang ada pada PT.International Nicel Indonesia.

Tujuan PLTA adalah untuk mencukupi kebutuhan sistem akan energi, kapasitas (tenaga), dan kapasitas cadangan bila terjadi kebutuhan yang tidak terduga atau kehilangan satuan pembangkit dengan biaya yang minimal. Kebutuhan air untuk PLTA didasarkan pada kapasitas listrik rencana. Penentuan kapasitas tenaga rencana tergantung pada ketersediaan air untuk memutar turbinnya. PLTA dapat mengatasi dan sangat efisien untuk tercukupinya kebutuhan tenaga puncak. M.M. Dandekar (1991) mengemukakan bahwa daya yang tersedia pada suatu waduk dapat di hitung dengan rumus dibawah ini :

$$
\mathrm{P}=12 \mathrm{QH}
$$

dengan, $\mathrm{P}$ adalah daya listrik (watt), $\mathrm{Q}$ adalah debit masuk turbin $\left(\mathrm{m}^{3} / \mathrm{det}\right)$, dan $\mathrm{H}$ adalah tinggi efektif $(\mathrm{m})$.

Prinsip dari fungsi waduk adalah menampung air saat debit air tinggi untuk digunakan saat debit air rendah (Sudjarwadi, 1989). Hal ini berarti bahwa waduk mempunyai tugas membuat modifikasi dari distribusi air menurut alam menjadi distribusi air buatan. Kebutuhan air yang direncanakan dalam hal ini diperuntukkan untuk memenuhi kebutuhan perusahaan sebagai tolak ukur efisiensi dalam meningkatkan pengelolaan biji nickel pada perusahaan tersebut, dalam hal ini kebutuhan air hanya untuk memenuhi PT.INCO sebagai pembangkit tenaga listrik dalam memutar turbin untuk pengolahan biji nikel. Kebutuhan air untuk tenaga listrik, dihitung berdasarkan besarnya laju aliran air (debit) melalui turbin, yang digunakan sebagai pembangkit tenaga listrik yang besarnya ditentukan oleh pihak perusahaan.

Pengambilan keputusan untuk menentukan suatu investasi layak atau tidak layak, harus didasarkan pada kajian aspek finansial dan ekonomi, kajian aspek finansial bertujuan untuk mengetahui pergerakan aliran keuangan, sedang kajian aspek ekonomi bertujuan untuk mendapatkan manfaat terhadap biaya (Imam Suharto, 1995). Kemandirian ekonomi pada Waduk Batu Besi akan tercapai apabila pendapatan yang diperoleh dari air yang dilepas waduk lebih besar dari biaya yang dikeluarkan waduk. Berdasarkan pertimbangan kemandirian ekonomi tersebut maka analisis pada model pengelolaan ekonomi waduk Batu Besi akan menujukkan hasil bahwa Waduk Batu Besi memiliki kemandirian ekonomi, terutama dalam kemampuan mengembalikan pinjaman (biaya investasi untuk pembangunan Waduk Batu Besi) dan mampu membiayai kegiatan operasi dan pemeliharaan waduk itu sendiri.

Semua kebutuhan air yang menjadi target dapat dilepas (release) atau dipenuhi oleh Waduk Batu Besi, ditentukan sepanjang tahun mulai dari tahun 1998 sampai tahun 2035 untuk kemudian digunakan dalam pengoperasian pengaturan air waduk. Total produksi listrik secara eksisting yang tercatat $\left(\mathrm{Gwh}_{\mathrm{observasi}}\right)$ dari tahun 1998 hingga tahun 2004 dapat terlihat dibawah ini :

Tabel 1. Total produksi listrik maksimum PLTA waduk Batu Besi

\begin{tabular}{|c|c|c|c|}
\hline \multirow{2}{*}{ TAHUN } & \multicolumn{2}{|c|}{ Total Produksi } & Eficiency \\
\cline { 2 - 4 } & Gwh tercatat & Gwhterhitung & 0,638 \\
1998 & 955 & 1497,75 & 0,745 \\
2000 & 1.272 & 1707,02 & 0,938 \\
2001 & 1.845 & 1967,02 & 0,986 \\
2002 & 2.150 & 2181,24 & 0,974 \\
2003 & 2.011 & 2064,56 & 0,974 \\
2004 & 1.977 & 2030,54 & 0,969 \\
\hline Rerata & 2.084 & 2151,7 & 0,89 \\
\hline
\end{tabular}


Total produksi Listrik Maksimum yang terjadi sejak pertama kali PLTA beroperasi pada tahun 1998 hingga tahun 2004 (1998-2004) sebesar 2151,7 Gwh. Total produksi Listrik maksimum yang terhitung $\left(\mathrm{Gwh}_{\text {terhitung }}\right)$ pada tahun 2001 sebesar 2181,24 Gwh. Total produksi Listrik baik secara eksisting maupun yang terhitung, diperoleh nilai efisiensi rerata dimana perbandingan antara besarnya $\mathrm{Gwh}_{\text {tercatat }}$ dan $\mathrm{Gwh}_{\text {terhitung }}$ sebesar 0,89 sepanjang tahun 1998 hingga tahun 2004.

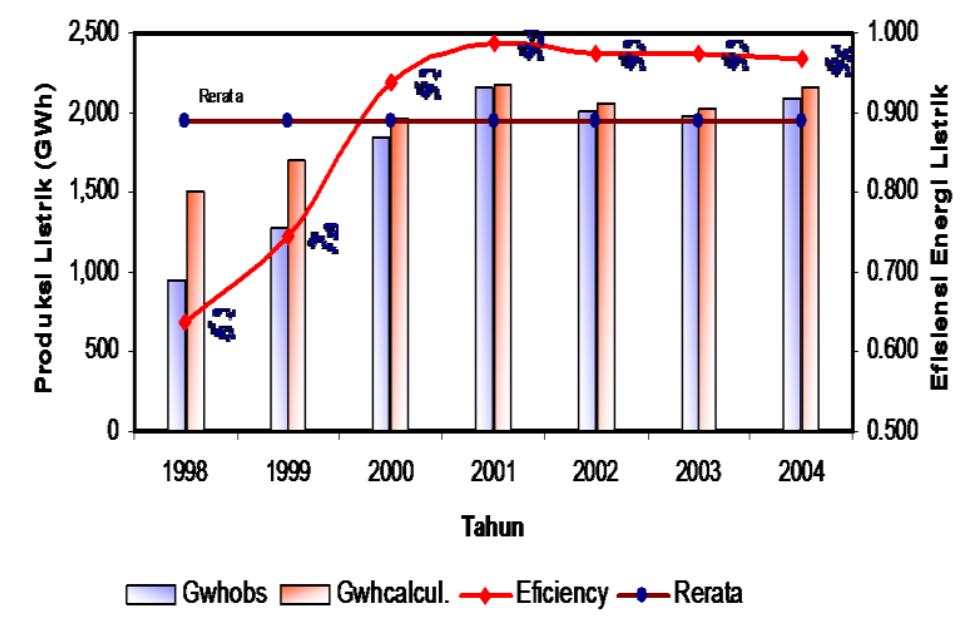

Gambar 1. Hubungan antara besarnya produksi listrik dan efisiensi

Hasil analisis produksi listrik pada PLTA waduk Batu Besi sejak tahun 1998 hingga tahun 2004 dapat dilihat pada tabel 2 di bawah ini.

Tabel 2. Tabel analisis produksi listrik (Gwh) pada PLTA waduk Batu besi

\begin{tabular}{|c|c|c|c|c|c|c|c|c|c|c|c|c|}
\hline Talun & Jan & Feb & Maret & Apoll & Mei & Juni & Juili & Aoyst & Sept & Otio & Nov & Dess \\
\hline 1998 & 117.11 & 137.0.2 & 100.75 & 124.56 & 134.71 & 120.84 & 166.24 & 119.00 & 111.85 & 118.58 & 129.87 & 127.63 \\
\hline 1999 & 136.78 & 120.40 & 148.74 & 148.71 & 153.61 & 144.80 & 166.14 & 133.62 & 130.24 & 156.80 & 13990 & 14.26 \\
\hline 2000 & 100.37 & 147.35 & 102.31 & 164.14 & 167.92 & 153.99 & 15249 & 154.98 & 160.96 & 182.46 & 179.20 & 1008.84 \\
\hline 2001 & 1771.76 & 1026.65 & 1727.74 & 170.39 & 174.99 & 1668.82 & 166.80 & 161.93 & 184.86 & 1980.02 & 201.13 & 27,15 \\
\hline 2002 & 189.19 & 162.15 & 171.25 & 157.68 & 176.63 & 165.76 & 1027.76 & 1688.88 & 100.64 & 170.87 & 196.22 & 181.62 \\
\hline 2003 & 165.58 & 130.80 & 159599 & 156.69 & 170.15 & 1620.03 & 153.66 & 170.97 & 169.71 & 186888 & $213: 13$ & 100.13 \\
\hline 2004 & 192532 & 152.01 & 170.88 & 164,03 & 168.68 & 102.51 & 175.02 & 169.80 & 169.72 & 186.33 & 188.37 & 19221 \\
\hline
\end{tabular}

Hasil analisis kemampuan ekonomi waduk Batu Besi dapat bahwa pendapatan total dari tahun 1998 hingga tahun 2004 adalah Rp4.817.751,191,sedangkan total pendapatan fasilitas perusahaan adalah sebesar Rp 856.620.818,941,. Hal tersebut menunjukan bahwa waduk Batu Besi memiliki kemandirian ekonomi. Dengan demikian dapat dikatakan bahwa waduk Batu Besi apabila dikelola dengan hanya mengandalkan pendapatan atas air saja sudah mampu membiayai waduk untuk kepentingan pengembalian investasi serta operasi dan pemeliharaan perusahaan, Apabila waduk hanya dibebani biaya operasi dan pemeliharaan waduk saja, waduk tersebut sudah mampu beroperasi secara baik.

Analisis nilai ekonomi air pada waduk Batu Besi dalam memutar turbin mampu menghasilkan daya listrik sebagai tolak ukur efisiensi tercapainya 
produktivitas pengelolaan biji nikel dalam memproduksi secara maksimal dari pemanfaatan air pada Waduk Batu Besi.

Waduk diharapkan dapat memberikan pendapatan kepada perusahaan tersebut sehingga dengan tarif dasar listrik yang tinggi mampu memberikan pendapatan yang besar dalam hal meningkatkan hasil produktivitas nikel bagi perusahaan.

\section{HASIL DAN PEMBAHASAN}

Dalam penelitian ini waduk Batu Besi disimulasikan dengan menggunakan model pengelolaan atas air waduk yang mampu meningkatkan daya listrik untuk memproduksi nikel secara maksimal, sehingga dalam hal ini mampu meningkatkan produktivitas nikel pada PT. International Nickel Indonesian.

Tabel 3. Analisis produksi listrik pada PLTA waduk Batu Besi (GWh)

\begin{tabular}{|c|c|c|c|c|c|c|c|c|c|c|c|c|}
\hline Talun & Jan & Feb & Waret & Apoil & Mei & Juni & Julli & Aqust & Seppt & Okio & Nov & Des \\
\hline 1998 & 117,11 & 137,02 & 130,75 & 124,56 & 134,71 & 129,84 & 116,24 & 119,00 & 1111,85 & 118,58 & 129,87 & 127,63 \\
\hline 1999 & 136,78 & 120,49 & 148,74 & 188,71 & 153,61 & 144,83 & 146,14 & 133,62 & 130,24 & 156,80 & 139,00 & 144,26 \\
\hline 2000 & 160,37 & 147,35 & 162,31 & 164,14 & 167,92 & 153,99 & 152,49 & 154,98 & 160,96 & 182,46 & 179,20 & 100,84 \\
\hline 2001 & 171,76 & 162655 & 172,74 & 170,39 & 177,99 & 168,82 & 166,80 & 161,93 & 184,86 & 198,02 & 201,13 & 217,15 \\
\hline 2002 & 1899,19 & 163,05 & 171,25 & 157,68 & 176,63 & 165,76 & 162,76 & 1668,80 & 1000,64 & 170,87 & 1960,22 & 181,02 \\
\hline 2003 & 165,58 & 130,83 & 159,59 & 156,69 & 170,15 & 163,03 & 153,66 & 170,97 & 169,71 & 180,80 & 213,13 & 190,13 \\
\hline 2004 & 192,32 & 152,01 & 170,88 & 164,03 & 168,68 & 162,51 & 175,02 & 169,80 & 169,72 & 180,33 & 188,37 & 192,21 \\
\hline
\end{tabular}

Tabel 4. Total produksi listrik berdasarkan inflow yang diperoleh

\begin{tabular}{|c|c|c|}
\hline TAHUN & Gwh $_{\text {terhitung }}$ & Gwh tercatat $_{\text {te }}$ \\
\hline 1998 & 1909,6 & 955 \\
\hline 1999 & 1884,09 & 1272 \\
\hline 2000 & 1960,65 & 1845 \\
\hline 2001 & 2173,78 & 2150 \\
\hline 2002 & 2044,09 & 2011 \\
\hline 2003 & 2023,18 & 1977 \\
\hline 2004 & 2124 & 2084 \\
\hline 2005 & 1488,71 & 955 \\
\hline 2006 & 1469,93 & 1272 \\
\hline 2007 & 1909,59 & 1845 \\
\hline 2008 & 2089,4 & 2150 \\
\hline 2009 & 2011,73 & 2011 \\
\hline 2010 & 1957,13 & 1977 \\
\hline 2011 & 1933,33 & 2084 \\
\hline 2012 & 1476,18 & 955 \\
\hline 2013 & 1511,01 & 1272 \\
\hline 2014 & 1906,55 & 1845 \\
\hline 2015 & 2092,27 & 2150 \\
\hline 2016 & 2007,72 & 2011 \\
\hline 2017 & 1954 & 1977 \\
\hline 2018 & 1933 & 2084 \\
\hline 2019 & 1488,74 & 955 \\
\hline 2020 & 1495,72 & 1272 \\
\hline 2021 & 1510,32 & 1845 \\
\hline 2022 & 2090,36 & 2150 \\
\hline 2023 & 2007,36 & 2011 \\
\hline 2024 & 1950,57 & 1977 \\
\hline 2025 & 1933,33 & 2084 \\
\hline 2026 & 1494 & 955 \\
\hline 2027 & 1495,44 & 1272 \\
\hline 2028 & 1914,04 & 1845 \\
\hline 2029 & 2096,28 & 2150 \\
\hline 2030 & 1500,62 & 2011 \\
\hline 2031 & 1955,6 & 1977 \\
\hline 2032 & 1933,33 & 2084 \\
\hline 2033 & 1500,9 & 955 \\
\hline 2034 & 1505,43 & 1272 \\
\hline 2035 & 1909,31 & 1845 \\
\hline & & \\
\hline
\end{tabular}


Berdasarkan hal tersebut maka anggaran tahunan yang digunakan untuk kegiatan operasi dan pemeliharaan waduk Batu Besi yang menjadi beban perusahaan dapat diminimalkan. Namun untuk menerapkan sistem tersebut tentunya diperlukan pengaturan yang spesifik dalam pengelolaan badan pengelola waduk. Berikut total pendapatan perusahaan serta untung bersih yang diperoleh dari besarnya daya listrik yang terpakai (Gwh), sesuai dengan pengalokasiannya pada perusahaan International Nickel Indonesia, terlihat pada tabel sebagai berikut :

Tabel 5. Total pendapatan dan untung bersih fasilitas perusahaan

\begin{tabular}{|c|c|c|c|}
\hline TAHUN & $\begin{array}{l}\text { Total pendapatan } \\
\text { (Rp/GWH) }\end{array}$ & $\begin{array}{c}\text { Total pendapatan } \\
\text { Fasilitas Perusahaan } \\
(\mathrm{Rp} / \mathrm{GWH})\end{array}$ & $\begin{array}{l}\text { Untung Bersih } \\
\text { Pendapatan Fasilitas } \\
\text { Perusahaan } \\
\text { (Rp/GWH) }\end{array}$ \\
\hline 1998 & $643.969 .283 .775,653$ & $125.563 .863 .761,403$ & $518.405 .420 .014,250$ \\
\hline 1999 & $641.780 .449 .979,480$ & $113.075 .619 .040,025$ & $528.704 .830 .939,454$ \\
\hline 2000 & $665.620 .683 .975,921$ & $117.079 .145 .090,553$ & $548.541 .538 .885,368$ \\
\hline 2001 & $746.762 .311 .821,763$ & $134.810 .932 .983,018$ & $611.951 .378 .838,745$ \\
\hline 2002 & $678.405 .275 .292,135$ & $117.696 .937 .094,173$ & $560.708 .338 .197,962$ \\
\hline 2003 & $682.378 .272 .258,474$ & $117.969 .570 .039,959$ & $564.408 .702 .218,515$ \\
\hline 2004 & $758.834 .914 .513,442$ & $130.424 .750 .931,998$ & $628.410 .163 .581,444$ \\
\hline 2005 & $501.911 .708 .284,763$ & $125.563 .863 .761,403$ & $376.347 .844 .523,360$ \\
\hline 2006 & 499.079.300.708,208 & $113.075 .619 .040,025$ & $386.003 .681 .668,183$ \\
\hline 2007 & 499.322.699.539,393 & $117.079 .145 .090,553$ & $382.243 .554 .448,840$ \\
\hline 2008 & 499.079.300.708,208 & $134.810 .932 .983,018$ & $364.268 .367 .725,190$ \\
\hline 2009 & $505.012 .068 .281,780$ & 117.696.937.094,173 & $387.315 .131 .187,607$ \\
\hline 2010 & $506.296 .025 .559,418$ & $117.969 .570 .039,959$ & $388.326 .455 .519,458$ \\
\hline 2011 & $505.479 .814 .592,538$ & $130.424 .750 .931,998$ & $375.055 .063 .660,541$ \\
\hline 2012 & $501.911 .708 .284,763$ & $125.563 .863 .761,403$ & $376.347 .844 .523,360$ \\
\hline 2013 & 499.079.300.708,208 & $113.075 .619 .040,025$ & $386.003 .681 .668,183$ \\
\hline 2014 & 499.322.699.539,393 & $117.079 .145 .090,553$ & $382.243 .554 .448,840$ \\
\hline 2015 & 499.079.300.708,208 & $134.810 .932 .983,018$ & $364.268 .367 .725,190$ \\
\hline 2016 & $505.012 .068 .281,780$ & $117.696 .937 .094,173$ & $387.315 .131 .187,607$ \\
\hline 2017 & $506.296 .025 .559,418$ & $117.969 .570 .039,959$ & $388.326 .455 .519,458$ \\
\hline 2018 & $505.479 .814 .592,538$ & $130.424 .750 .931,998$ & $375.055 .063 .660,541$ \\
\hline 2019 & $641.780 .449 .979,480$ & $113.075 .619 .040,025$ & $528.704 .830 .939,454$ \\
\hline 2020 & $665.620 .683 .975,921$ & $117.079 .145 .090,553$ & $548.541 .538 .885,368$ \\
\hline 2021 & $746.762 .311 .821,763$ & $134.810 .932 .983,018$ & $611.951 .378 .838,745$ \\
\hline 2022 & $678.405 .275 .292,135$ & $117.696 .937 .094,173$ & 560.708.338.197,962 \\
\hline 2023 & $682.378 .272 .258,474$ & $117.969 .570 .039,959$ & $564.408 .702 .218,515$ \\
\hline 2024 & $758.834 .914 .513,442$ & $130.424 .750 .931,998$ & $628.410 .163 .581,444$ \\
\hline 2025 & $643.969 .283 .775,653$ & $125.563 .863 .761,403$ & $518.405 .420 .014,250$ \\
\hline 2026 & $641.780 .449 .979,480$ & $113.075 .619 .040,025$ & $528.704 .830 .939,454$ \\
\hline 2027 & $665.620 .683 .975,921$ & $117.079 .145 .090,553$ & $548.541 .538 .885,368$ \\
\hline 2028 & $746.762 .311 .821,763$ & $134.810 .932 .983,018$ & $611.951 .378 .838,745$ \\
\hline 2029 & $678.405 .275 .292,135$ & $117.696 .937 .094,173$ & $560.708 .338 .197,962$ \\
\hline 2030 & $682.378 .272 .258,474$ & $117.969 .570 .039,959$ & $564.408 .702 .218,515$ \\
\hline 2031 & $758.834 .914 .513,442$ & $130.424 .750 .931,998$ & $628.410 .163 .581,444$ \\
\hline 2032 & $643.969 .283 .775,653$ & $125.563 .863 .761,403$ & $518.405 .420 .014,250$ \\
\hline 2033 & $641.780 .449 .979,480$ & $113.075 .619 .040,025$ & $528.704 .830 .939,454$ \\
\hline 2034 & $665.620 .683 .975,921$ & $117.079 .145 .090,553$ & $548.541 .538 .885,368$ \\
\hline 2035 & $746.762 .311 .821,763$ & $134.810 .932 .983,018$ & $611.951 .378 .838,745$ \\
\hline
\end{tabular}

Dapat dikemukakan bahwa waduk Batu Besi mampu membiayai untuk kepentingan pengembalian investasi pada perusahaan dan membiayai seluruh kegiatan operasi serta pemeliharaan pada waduk tersebut. 


\section{PENUTUP}

\section{Kesimpulan}

Pengembalian investasi atau modal untuk pembangunan waduk Batu Besi tetap menjadi beban perusahaan namun pendapatan yang diperoleh dapat dialokasikan guna pemeliharaan waduk sepanjang pengelolaan umur waduk yang direncanakan. Pemanfaatan air untuk PLTA pada Waduk Batu Besi mulai dari tahun awal waduk berfungsi sampai akhir umur waduk tahun 2035 memiliki kecenderungan untuk naik, maka Waduk Batu Besi memiliki kemandirian ekonomi, terutama dalam mengembalikan pinjaman (biaya investasi) serta mampu membiayai kegiatan operasi dan pemeliharaan waduk. Namun dengan nilai tersebut Waduk Batu Besi dapat memberikan pemasukan pendapatan bagi pemerintah daerah sebagai dasar dalam menentukan kebijakan tentang pemanfaatan air waduk Batu Besi.

Saran

Mengingat pentingnya ketersediaan data tersebut, dalam menunjang keakuratan hasil analisis kemandirian ekonomi dari waduk sebagai dasar dalam menentukan kebijakan tentang pemanfaatan air waduk, maka disarankan pencatatan data inflow dan outflow waduk tersebut perlu dilakukan secara terus menerus selama masa perencanaan umur waduk.

\section{DAFTAR PUSTAKA}

Aris Munandar, Kuwahara, 2004, Pembangkitan Dengan Tenaga Air, PT. Pradnya Paramita, Jakarta.

Dahlan Abubakar, Asdar Muis RMS, 2004, Inco Mengalir di Tengah Gejolak Pertambangan, PT.Inco, Sulawesi Selatan.

Dandeker, M.M, 1991, Pembangkit Listrik Tenaga Air, Universitas Indonesia, Jakarta.

Hessel Nogi S. Tangkilisan, 2003, Memahami Kinerja Keuangan Perusahaan, Balairung \& Co, Yogyakarta.

Imam Soeharto,CD, 1995, Hidrologi Teknik, Erlangga, Jakarta.

Jayadi, R,2000, Optimasi Dan Simulasi Pengembangan Sumberdaya Air, Jurusan Teknik Sipil, Fakultas Teknik, Universitas Gadjah Mada, Yogyakarta.

Nurrochmad, F, 2003, Bahan Kuliah Pengembangan Sumberdaya Air, MPSA, Universitas Gadjah Mada, Yogyakarta.

Patty, O.F, 1995, Tenaga Air, Erlangga, Jakarta.

Pranoto.S, 1993, Optimasi Pemanfaatan Air Das serayu dengan menggunakan metode Linier dan simulasi, Teknik Sipi ITB, Bandung.

Robert J. Kodoatie, 2005, Analisis Ekonomi Teknik, Andi Yogyakarta.

Sari,YC, 2001, Optimasi Pengelolaan Waduk Sangiran dari Sisi Ekonomi, Program Pascasarjana, Universitas Gadjah Mada, Yogyakarta.

Sholeh,M, 1999, Hidrologi, Jurusan Teknik Sipil, Fakultas Teknik Sipil dan Perencanaan, Institut Teknologi Sepuluh Nopember, Surabaya.

Soedibyo, 2003, Teknik Bendungan, Pradnya Paramita, Jakarta.

Soehoed.A.R., 2005, Pertambangan dan Pembangunan Daerah, Aksara Karunia, Jakarta.

Sudjarwadi,1989, Operasi Waduk, PAU Ilmu Ilmu Teknik, Universitas Gadjah Mada, Yogyakarta. 
Triatmodjo,B, 2001, Diktat Hidrologi, Jurusan Teknik Sipil, Fakultas Teknik, Universitas Gadjah Mada, Yogyakarta.

Yekti, 2000, Analisis Optimasi Operasi Waduk Sermo, Program Pascasarjana, Universitas Gadjah Mada, Yogyakarta. 
PENA TEKNIK: Jurnal Ilmiah Ilmu-Ilmu Teknik

Volume 1, Nomor 1, Maret $2016: 55$ - 62 